Vozel D, Steiner N, Božanić Urbančič N, Mladenov D, Battelino S. Slovenian cross-cultural adaptation and validation of health-related quality of life measures for chronic otitis media (COMQ-12), vertigo (DHI, NVI) and tinnitus (THI). Zdr Varst. 2020;59(3):120-127. doi: 10.2478/sjph-2020-00016.

\title{
SLOVENIAN CROSS-CULTURAL ADAPTATION AND VALIDATION OF HEALTH-RELATED QUALITY OF LIFE MEASURES FOR CHRONIC OTITIS MEDIA (COMQ-12), VERTIGO (DHI, NVI) AND TINNITUS (THI) MEDKULTURNA PRILAGODITEV IN POTRDITEV SLOVENSKIH RAZLIČIC VPRAŠALNIKOV ZA OCENO KRONIČNEGA VNETJA SREDNJEGA UŠESA (COMQ-12), VRTOGLAVICE (DHI, NVI) IN TINITUSA (THI)
}

\author{
Domen VOZEL ${ }^{1,2}$, Nejc STEINER ${ }^{1}$, Nina BOŽANIĆ URBANČIČ1,2, Dejan MLADENOV ${ }^{3}$ Saba BATTELINO ${ }^{1,2^{*}}$ \\ 'University Medical Centre Ljubljana, Department of Otorhinolaryngology \\ and Cervicofacial Surgery, Zaloška 2, 1000 Ljubljana, Slovenia \\ 2University of Ljubljana, Faculty of Medicine, Department of Otorhinolaringology, \\ Vrazov trg 2, 1000 Ljubljana, Slovenia \\ 3Železniški zdravstveni dom Ljubljana, Celovška cesta 4, 1000 Ljubljana, Slovenia
}

ABSTRACT

Keywords: quality of life, surveys and questionnaires, tinnitus, vertigo, otitis media, dizziness

\section{IZVLEČEK}

Ključne besede: kakovost življenja, ankete in vprašalnik, tinitus, vrtoglavica, vnetje srednjega ušesa, nestabilnost
Purpose: To provide physicians and patients with the tools needed to evaluate patients' problems and health-related quality of life by cross-culturally adapting and validating the Chronic Otitis Media Questionnaire 12 (COMQ-12), the Dizziness Handicap Inventory (DHI), the Neuropsychological Vertigo Inventory (NVI) and the Tinnitus Handicap Inventory (THI).

Materials and methods: COMQ-12, DHI, NVI and THI were translated into the Slovenian language and completed by patients treated at our department for chronic otitis media, vertigo or tinnitus. The control group for each questionnaire consisted of healthy volunteers. Internal consistency, test-retest reliability, discriminant validity, diagnostic accuracy and cut-off value were determined for each questionnaire.

Results: Test-retest reliability was excellent for DHI (ICC $A=0.946)$ and NVI ( $p=0.315$, ICC $A=0.975)$, good to excellent for COMQ-12 $(p=0.680$, ICC $A=0.858)$ and satisfactory for THI $(p=0.120)$. Discriminant validity was confirmed for each questionnaire $(\mathrm{p}>0.05)$ using the Mann-Whitney $\mathrm{U}$ test (COMQ-12, DHI, THI) or the Welch t-test (NVI). COMQ-12 had acceptable $(\alpha=0.796)$ and $\mathrm{DHI}(\mathrm{a}=0.910)$, NVI $(\alpha=0.950)$ and THI $(\mathrm{a}=0.924)$ perfect internal consistency. COMQ-12 and DHI had excellent, NVI acceptable and THI perfect diagnostic accuracy (AUC=0.987, AUC=0.999, AUC $=0.781$ and $A U C=1.000$ respectively). Cut-off values determined by Youden's index were 7, 7, 9 and 56 for COMQ-12, THI, DHI and NVI, respectively.

Conclusion: Slovenian COMQ-12, DHI, NVI and THI are a valid and accurate tool for the diagnosis and measurement of health-related quality of life in patients with chronic otitis media, vertigo and tinnitus. They could aid general practitioners, occupational health specialists, neurologists and otorhinolaryngologists.

Namen: Orodja za oceno težav bolnikov s kroničnimi vnetji srednjega ušesa, težav z ravnotežjem in tinitusom ter vpliv slednjih na kakovost življenja v slovenščini ne obstajajo. S projektom smo jih želeli zagotoviti zdravnikom in bolnikom s temi težavami. Vrzel bi zapolnili z medkulturno prilagoditvijo in potrditvijo vprašalnika o kroničnem vnetju srednjega ušesa (COMQ-12), vrtoglavici (DHI), nevropsiholoških vplivih vrtoglavice (NVI) in o obremenjenosti zaradi tinitusa (THI).

Metode: Vprašalniki so bili prevedeni iz angleščine $v$ slovenščino skladno s priporočili. COMQ-12 so izpolnili bolniki s kroničnim vnetjem srednjega ušesa, DHI in NVI z vrtoglavico in THI s tinitusom. Kontrolno skupino za vsak vprašalnik so sestavljali zdravi prostovoljci. Vsakemu vprašalniku je bila določena stopnja notranje skladnosti, zanesljivost pri ponovnem testiranju, diskriminantna validnost, diagnostična natančnost in mejna vrednost.

Rezultati: Zanesljivost pri ponovnem testiranju je bila odlična za DHI $(I C C A=0,946)$ in NVI $(p=0,315, I C C A=0,975)$, dobra do odlična za COMQ-12 ( $p=0,680, I C C A=0,858)$ in zadovoljiva za THI $(p=0,120)$. Diskriminantna validnost je bila potrjena $(p>0,05)$ za vsak vprašalnik bodisi z uporabo testa Mann-Whitney U (COMQ-12, DHI, THI) bodisi z Welchovim t-testom (NVI). COMQ-12 je imel sprejemljivo $(a=796)$, DHI $(a=0,910), N V I(a=0,950)$ in THI $(a=0,924)$ pa popolno notranjo skladnost. COMQ-12 in DHI sta imela odlično $(0,987$ in 0,999$)$, NVI sprejemljivo $(0,781)$ in THI popolno $(1,000)$ diagnostično natančnost glede na vrednost površine pod krivuljo ROC. Mejne vrednosti so bile določene objektivno z Youdonovim indeksom $(J)$ in so znašale 7 za COMQ-12 $(J=0,90)$ in $\operatorname{THI}(J=1,00)$, 9 za DHI $(J=0,95)$ in 56 za NVI $(J=0,43)$.

Zaključek: Slovenske različice vprašalnikov COMQ-12, DHI, NVI in THI so medkulturno prilagojene, potrjene in uporabne kot pomembna merila za oceno z zdravjem povezane kakovosti življenja. Hkrati so tudi natančen diagnostični pripomoček pri bolnikih s kroničnim vnetjem srednjega ušesa, vrtoglavico ali tinitusom, ki bo $v$ pomoč zdravnikom specialistom družinske medicine, specialistom medicine dela, prometa in športa, nevrologom ter otorinolaringologom. 


\section{INTRODUCTION}

Patient-reported health-related quality-of-life (HRQoL) questionnaires are an indispensable tool for general practitioners, occupational health specialists and physicians of other medical specialisations when approaching a variety of medical conditions. They provide subjective information about the patient's health status, and complement the objective findings of clinical examination or diagnostic procedures (1-3). They also play an important role in assessing treatment efficacy in many otorhinolaryngologic diseases (4).

Chronic otitis media (COM), dizziness and tinnitus are common diseases and symptoms that can have a great impact on HRQoL. Different questionnaires are therefore available in various languages to assess it. Moreover, as there is a common overlap of COM, dizziness and tinnitus-associated complaints in a single patient, it is appropriate to provide multiple questionnaires to assess these complaints. COMQ-12, DHI, NVI and THI are useful questionnaires to determine physical, cognitive, socioeconomic and emotional neuropsychological influences of the disease on HRQoL (5-8).

When modifying a questionnaire from an original to the desired target language, a thorough process of crosscultural adaptation and validation is required, rather than a simple translation (9). It appears that this process may present a certain obstacle as, to the best of our knowledge, no such questionnaires for patients with COM, dizziness and tinnitus have yet been produced in the Slovenian language.

There is therefore a desire to provide such questionnaires to physicians dealing with patients with COM, dizziness and tinnitus in Slovenia. For that reason, the purpose of our study was to cross-culturally adapt and validate Chronic Otitis Media Questionnaire 12 (COMQ-12), the Dizziness Handicap Inventory (DHI), the Neuropsychological Vertigo Inventory (NVI) and the Tinnitus Handicap Inventory (THI) into the Slovenian language for the first time. Furthermore, Slovenian versions of COMQ-12, DHI, NVI and THI would contribute to a further comparison of populations divided by culture or language.

\subsection{Chronic Otitis Media}

COM can be defined as at least three months of persistent middle ear inflammation with an associated permanent tympanic membrane defect. While inconsistent definitions of COM make the analysis of epidemiological data difficult, assessments of the burden presented by otitis media have been made. It is a leading reason why patients visit a doctor and are prescribed medication, and it places the brunt of the burden on developing countries (10). In some countries, the cost of treating ear infections is higher than the minimum monthly wage (11). The population of developed industrialised countries, including Slovenia, is the least at risk (10). COM causes disabling hearing loss, impedes speech development and involvement in education, and makes it more difficult to find and retain employment in jobs that require high levels of qualification (12). Additionally, patients with COM are affected by ear discharge, ear discomfort, balance disorders, tinnitus and mental disorders, all of which lead to poorer quality of life and higher levels of absenteeism $(13,14)$. HRQoL patientreported questionnaires are therefore an important adjunct to the management of patients with COM (5).

\subsection{COMQ-12}

At least five patient-reported HRQoL questionnaires are available to assess the quality of life of COM patients. COMQ-12, and ZCMEI-21 are upgrades of CES, COMOT-15, COM-5. COMQ-12 is shorter than ZCMEI-21 $(14,15)$. Chronic Otitis Media Questionnaire 12 (COMQ-12) contains 12 questions: seven related to the severity of symptoms, two to the impact of the disease on lifestyle, two to the impact on healthcare and one general question. Each answer is given a score of $0-5$ points (14). A total score is also determined for persons without COM. Additionally, if the total score is $\leq 5$, surgical treatment should be reconsidered (16). The original English version has so far been translated into Turkish (5), Portuguese (17), Indian (18), Serbian (19) and Dutch (20, 21), etc.

\subsection{Vertigo}

Vertigo is defined as the perception of rotation or movement of an individual or objects in space. Patients often confuse it with symptoms of dizziness or visual or balance disturbance (7). In addition to the normal functioning of the vestibular apparatus, normal balance requires good vision and proprioception and good functioning of the central nervous system, which is where the integration of signals from these systems takes place. Damage to any of these structures can cause vertigo. Dizziness, impaired balance, vision, emotions, memory and self-perception may be associated with vertigo depending on the location of the dysfunction of the vestibular system. Understandably, patients often experience vertigo, dizziness and unsteadiness at the same time (rarely each of these symptoms individually). About $50 \%$ of people experience vertigo, $40 \%$ unsteadiness and $35 \%$ dizziness in one year (22). Vertigo and dizziness are also risk factors for falls, especially in the elderly (23). These problems lead to loss of an employment in $20 \%$ and reduction of work efficiency and social life impairment in $50 \%$ of cases (24). Vertigo and dizziness can therefore severely reduce quality of life and represent a major public health problem. For that reason, it is crucial to evaluate a patient's problems by means of patient-reported HRQoL questionnaires. 


\section{$1.4 \mathrm{DHI}$}

The $\mathrm{DHI}$ is a reference questionnaire (25) most commonly used to evaluate vertigo-associated problems (7). It has been developed to evaluate problems with balance, since the results of vestibulometry (e.g. caloric test) are often inconsistent with the clinical findings $(26,27)$. The DHI consists of 25 questions, 7 of which are related to physical, 9 to emotional and 9 to the functional influences of vertigo. The patient answers each question with "yes" ( 4 points), "sometimes" ( 2 points) or "no" 0 points). A higher total score means that vertigo has a more severe impact on the patient's quality of life. Four questions directly evaluate issues specific to the problems associated with benign paroxysmal positional vertigo (27). DHI has been translated into Swedish (28), Chinese (29), Dutch (30), Turkish (31), Italian (32), German (33), Spanish (34), Greek (6), etc.

\section{$1.5 \mathrm{NVI}$}

The NVI was developed in response to the absence of questionnaires that evaluate vertigo-related cognitive problems. It tests attention, memory, emotion, vision, motor skills, and spatial and time perception. It is therefore designed to assess patient-reported, vertigoassociated neuropsychological problems. The NVI has so far been made available in English and French (35). The French version consists of 28 and the English of 32 questions, containing 4 distractors $(7,35)$. The answer to each question is scored using the Likert scale (7). The English version without distractors was used to crossculturally adapt and validate the Slovenian NVI.

\subsection{Tinnitus}

Tinnitus is the perception of sound without a known external stimulus (36). In $8-17 \%$ of people, it occurs as temporary simple ringing after exposure to noise and it is rarely permanent (37). Its incidence increases with age and is present in $15 \%$ of people over the age of 65 (36, 37). In most cases, people do not seek medical attention because of tinnitus, as it does not significantly impact their daily life. However, it does have a significant impact on quality of life in some (36), and leads to hyperacusis, impaired cognitive ability, anhedonia, anxiety, depression and insomnia. Suicidality resulting from severe tinnitus has also been reported (37). Tinnitus can therefore interfere with daily activities (38) and affects the quality of life of certain personality types more significantly (38). The degree of tinnitus impairment also depends on tinnitus awareness throughout the day, the loudness and variability of the tinnitus, education, and additional physical symptoms (39). Although tinnitus can be determined audiometrically, patient-reported HRQoL questionnaires present an indispensable tool for evaluating tinnitus (40, 41).

\subsection{THI}

The THI is useful for evaluating tinnitus and its impact on HRQoL. It comprises 25 questions and is expected to complement the $\mathrm{DHI}$ in clinical practice. Twelve questions evaluate functional, eight emotional and five catastrophic responses to tinnitus. The patient answers each question with "yes" (4 points), "sometimes" ( 2 points) or "no" $(0$ points), where the maximum score is 100 . Scoring $78-100$ points means that the tinnitus is catastrophic, 58-76 severe, 38-56 moderate, $18-36$ mild and $<18$ light (42). The THI has been translated into Hungarian (43), Danish (44), Polish (45), Korean (46), Brazilian Portuguese (47), Turkish (48), Italian (49), Chinese $(50,51)$, French $(52,53)$, Hebrew (54), Russian (8), etc.

\section{MATERIALS AND METHODS}

\subsection{Translation and Cross-Cultural Adaptation of Questionnaires}

To enable replicability, the cross-cultural adaptation and validation processes are described according to the guidelines for translating and adapting hearing-related questionnaires for different languages and cultures by Hall et al. (9).

We conducted an initial review of the literature and were unable to locate any Slovenian versions of the COMQ-12, DHI, NVI or THI questionnaires. Permission to use the questionnaires was obtained from the authors of the original questionnaires. These authors were available for any additional questions regarding concepts or ambiguities behind the items. Literacy, population characteristics and the requirement for administrative help were evaluated for the target population. Template documents for recording the translation and adaptation process were created and the definition of concepts for each questionnaire item developed.

Two independent dual-language translators (native Slovenian speakers with a very good knowledge of English) were briefed on the questionnaires and their clinical concepts. They independently translated questionnaires into Slovenian (i.e. forward translation). The two translations were harmonised by two field experts to create a single translation.

Two independent dual-language translators (native English speakers with a very good knowledge of Slovenian) then independently translated the questionnaires back to the English language (i.e. back-translation). The two translations were reconciled by two field experts to create a single translation, which was then reviewed by the board of experts (one otosurgeon, one audiologist, two general otorhinolaryngology consultants, two otorhinolaryngology residents, one non-medical translation consultant). 
This was followed by pilot testing with the target audience (20 patients for each questionnaire) to ensure that the questions were understood and culturally appropriate. The results of the pilot testing were reviewed and the translation finalised. The same board of experts formatted and proofread the finalised translation. The questionnaires were then given to patients with COM, dizziness or tinnitus and to healthy volunteers. These subjects were later included in the statistical analysis.

\subsection{Subjects}

Patients treated at our department for COM, vertigo or tinnitus completed the COMQ-12, DHI, NVI or THI after an otorhinolaryngological check-up and confirmation of the diagnosis. The control groups for each questionnaire consisted of healthy volunteers, i.e. medical staff and their acquaintances or relatives. Every subject gave informed consent.

\subsection{Statistical Analysis}

After the cross-cultural adaptation of all the questionnaires, the validation was performed using various statistical methods; these are thoroughly described in order to enable replicability. Data were analysed using Microsoft Excel for Mac (version 16 and later) and SPSS (Statistical Package for the Social Sciences, version 23, IBM Corp., Armonk, NY, USA).

Internal consistency, test-retest reliability, discriminant validity, diagnostic accuracy and cut-off value were determined for each questionnaire. Internal consistency was determined with Cronbach's alpha and diagnostic accuracy and cut-off values using ROC curve analysis and Youden's index (55). Test-retest reliabilities and discriminant validities were determined by means of various statistical tests and depending on the analysed data.

\section{RESULTS}

The Slovenian translations of the COMQ-12, DHI, NVI and $\mathrm{THI}$ are available from the authors upon request and from the institution's official website.

\subsection{COMQ-12}

COMQ-12 was completed by 20 (52.6\%) male and 18 (47.7\%) female patients ( $P_{\text {сомQ-12 }}$ ) with an average age of $52.02 \pm 16.61$ years ( $M d n=55$ years, $R a=18-87$ years) and average score of $23.34 \pm 10.47 \quad(M d n=22, R a=4-51)$. The control group that completed COMQ-12 consisted of $10(16.4 \%)$ male and 51 (83.6\%) female volunteers with an average age of $37 \pm 10.53$ years $(M d n=35$ years, $R a=41$ years). They completed COMQ-12 twice within a two-day interval, hence test $\left(\mathrm{CT}_{\text {сомq-12 }}\right)$ and retest $\left(\mathrm{CRT}_{\text {сомq-12 }}\right)$. The average score was $1.410 \pm 3.111(M d n=0, R a=20)$ for $C_{\text {сомQ-12 }}$ and 1.246 $\pm 2.248(\mathrm{Mdn}=0, \mathrm{Ra}=9)$ for $\mathrm{CRT}_{\text {сомQ-12 }}$.

\subsection{DHI and NVI}

The DHI and NVI were each completed twice within a threeday interval by identical groups comprising 26 (43.3\%) male and 34 (56.7\%) female patients with an average age of $61.4 \pm 13.8$ years ( $M d n=63.5$ years, $R a=56$ years). The average score was $49.67 \pm 22.843(M d n=52, R a=86)$ for first completion of the $\mathrm{DHI}\left(\mathrm{PT}_{\mathrm{DHI}}\right)$ and $47.00 \pm 22.81$ $(M d n=49, R a=84)$ for the second completion $\left(P R T_{D H}\right)$. The average score was $65.07 \pm 18.78(\mathrm{Mdn}=65, \mathrm{Ra}=80)$ for first completion of the NVI $\left(\mathrm{PT}_{\mathrm{NVI}}\right)$ and 64.52 $\pm 18.88(\mathrm{Mdn}=65$, $\mathrm{Ra}=80$ ) for the second completion $\left(\mathrm{PRT}_{\mathrm{NVI}}\right)$. The $\mathrm{DHI}$ and $\mathrm{NVI}$ were completed by identical control groups comprising 28 (46.7\%) male and 32 (53.5\%) female volunteers with an average age of $46.6 \pm 16.2$ years $(M d n=45$ years, $R a=51$ years). The average score was $1.17 \pm 2.395(M d n=0, R a=10)$ for the $\mathrm{DHI}$ control group $\left(\mathrm{C}_{\mathrm{DHI}}\right)$ and $47.68 \pm 18.88(\mathrm{Mdn}=65$, $\mathrm{Ra}=80)$ for the NVI control group $\left(C_{\mathrm{NVI}}\right)$.

\subsection{THI}

The THI was completed by 19 (31.7\%) male and 41 (68.3\%) female patients $\left(P_{T H I}\right)$ with an average age of $53.80 \pm 13.7$ years ( $M d n=57$ years, $R a=59$ years) and an average score of $52.12 \pm 23.50 \quad(M d n=51, R a=88)$. The control group completed the THI twice over an interval of a few days. The THI was first completed by 19 (31.7\%) male and 41 (68.3\%) female volunteers with an average age of $37 \pm 10.53$ years $\left(\mathrm{Mdn}=35\right.$ years, $\mathrm{Ra}=41$ years) as a test group $\left(\mathrm{CT}_{\mathrm{THI}}\right)$. The retest group (CRT $\mathrm{THI}_{\mathrm{I}}$ ) consisted of three male (23.1\%) and ten female $(76.9 \%)$ volunteers recruited from the $\mathrm{CT}_{\mathrm{THI}}$ with an average age of $47.4 \pm 13.5$ years $(M d n=49$ years, $\mathrm{Ra}=52$ years) and average score of $0 \pm 0(\mathrm{Mdn}=0, \mathrm{Ra}=0)$.

\subsection{Statistical Analysis}

Test-retest reliability, discriminant validity, internal consistency, ROC curve analysis and cut-off value for each questionnaire are depicted in Table 1 and Figures 1, 2 and 3. 
Table 1. Test-retest reliability, discriminant validity, internal consistency, cut-off value and Youden's index for the COMQ-12, DHI, NVI and THI.

\begin{tabular}{|c|c|c|c|c|c|c|}
\hline & Test-retest reliability & $\begin{array}{l}\text { Discriminant } \\
\text { validity }\end{array}$ & $\alpha$ & $\mathrm{A}_{\mathrm{ROC}}$ & $\begin{array}{l}\text { Cut-off } \\
\text { value }\end{array}$ & $J$ \\
\hline COMQ-12 & $\mathrm{p}=0.680^{*}, \mathrm{ICC}_{\mathrm{A}}=0.858(0.774-0.912)^{* *}$ & $p<0.0005 \dagger$ & 0.796 & 0.987 & 7 & 0.90 \\
\hline $\mathrm{DHI}$ & $\begin{array}{l}I C C_{A}=0.946 \\
(0.902-0.969)^{* *}\end{array}$ & $p<0.0005 \dagger$ & 0.910 & 0.999 & 9 & 0.95 \\
\hline NVI & $\mathrm{P}=0.315 \neq, \mathrm{ICC} \mathrm{A}_{\mathrm{A}}=0.975(0.959-0.985)^{* *}$ & $\mathrm{p}<0.0005$ 扞 & 0.950 & 0.781 & 56 & 0.43 \\
\hline THI & $p=0.120^{*}$ & $p<0.0005 \dagger$ & 0.924 & 1.000 & 7 & 1.00 \\
\hline
\end{tabular}

Legend: $\alpha$, Cronbach's alpha; $\mathrm{A}_{\mathrm{ROC}}$, area under ROC curve; J, Youden's index; p, p-value; *, Wilcoxon signed-rank test; **, type A intraclass correlation coefficient estimates and their $95 \%$ confident intervals using an absolute agreement definition, based on single measures and two-way mixed effects (ICC $)$; $†$, Mann-Whitney $U$ test using an exact sampling distribution for $U$ (Dineen \& Blakesley, 1973); ‡, paired samples t-test; 扭, Welch’s t-test.

Commentary: statistical significance is $p<0.05$. As the minimum NVI score is 28 , the cut-off value is higher compared to the other questionnaires.

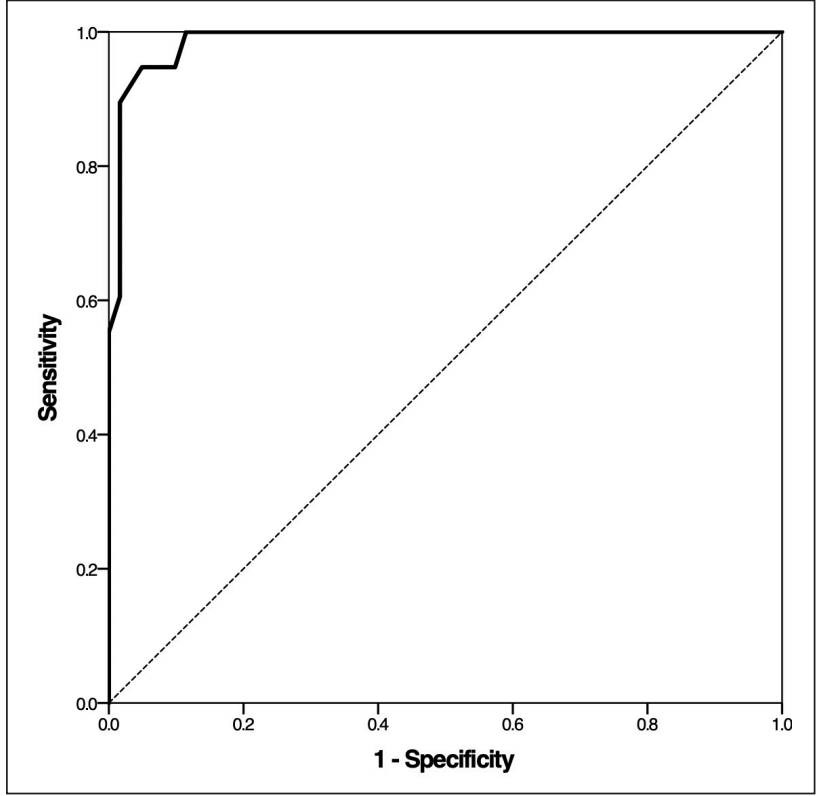

Commentary: The area under the ROC curve (0.987) signifies outstanding diagnostic accuracy. A threshold score of 7 was determined to distinguish between chronic otitis media and a healthy ear. The ROC curve was created by plotting $\mathrm{P}_{\text {сомQ-12 }}$ and $\mathrm{CT}_{\text {сомQ-12 }}$.

Figure 1. COMQ-12 ROC curve.

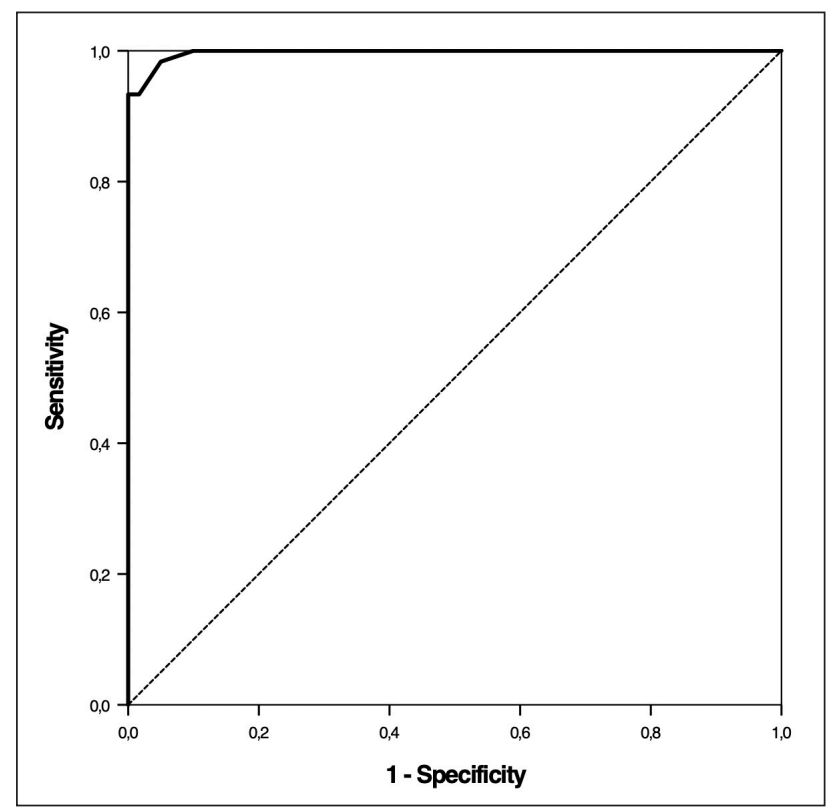

Commentary: The area under the ROC curve (0.999) signifies outstanding diagnostic accuracy. A threshold score of 9 was determined for the recognition of vertigo. The ROC curve was created by plotting $\mathrm{PT}_{\mathrm{DHI}}$ and $\mathrm{C}_{\mathrm{DHI}}$.

Figure 2. DHI ROC curve. 


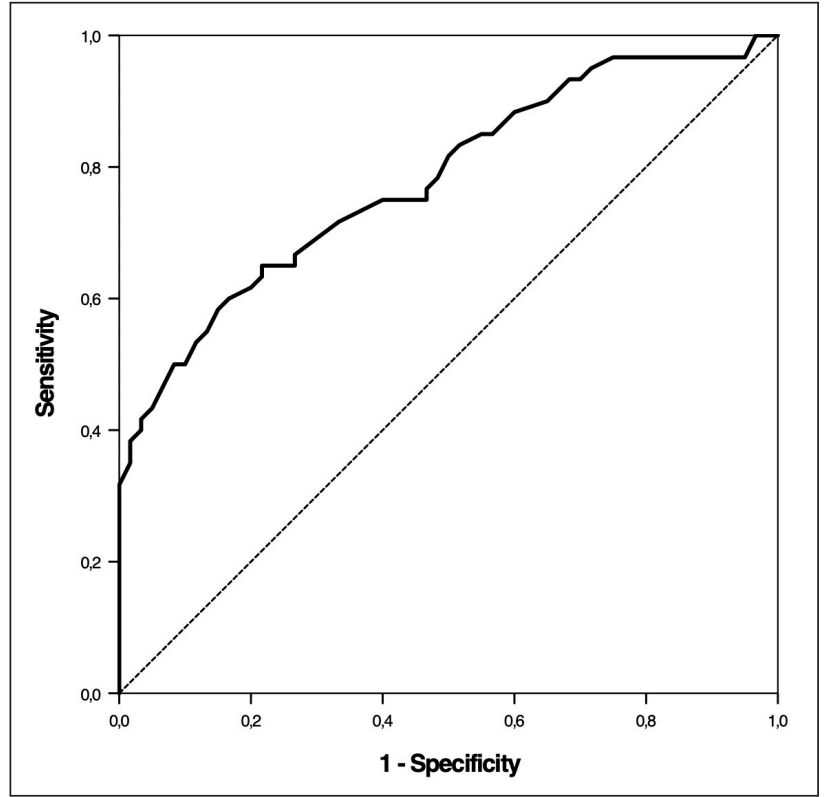

Commentary: The area under the ROC curve $(0.781)$ signifies acceptable diagnostic accuracy. A threshold score of 56 was determined for the recognition of vertigo. The ROC curve was created by plotting $\mathrm{PT}_{\mathrm{NVI}}$ and $\mathrm{C}_{\mathrm{NV}}$.

Figure 3. NVI ROC curve.

\section{DISCUSSION}

Each questionnaire had satisfactory test-retest reliability as determined by the intraclass correlation coefficient, the paired samples t-test or the Wilcoxon signed-rank test. Furthermore, the Slovenian COMQ-12 had good-toexcellent test-retest reliability, which was better than has been reported recently $(18,56)$. The Slovenian DHI had excellent test-retest reliability based on the intraclass correlation coefficient. This is consistent with other studies $(32,56)$. Since the NVI has only recently been developed, to the best of our knowledge no studies have yet been published regarding its test-retest reliability $(35,57)$. Instead, the Slovenian NVI possesses excellent test-retest reliability and contributes significantly to the current literature.

As in other studies, the discriminant validity was confirmed for the Slovenian COMQ-12, DHI and THI using the MannWhitney $U$ test and for the Slovenian NVI using Welch t-test by determining $p>0.05(5,7,53)$.

According to Cronbach's alpha, the Slovenian DHI, NVI and $\mathrm{THI}$ had perfect internal consistency, even higher compared to other studies $(7,8,32)$. The Slovenian COMQ12 had acceptable internal consistency.

To evaluate diagnostic accuracy and the cut-off value, the area under the ROC curve (AROC) and Youden's index were determined for each questionnaire. The Slovenian

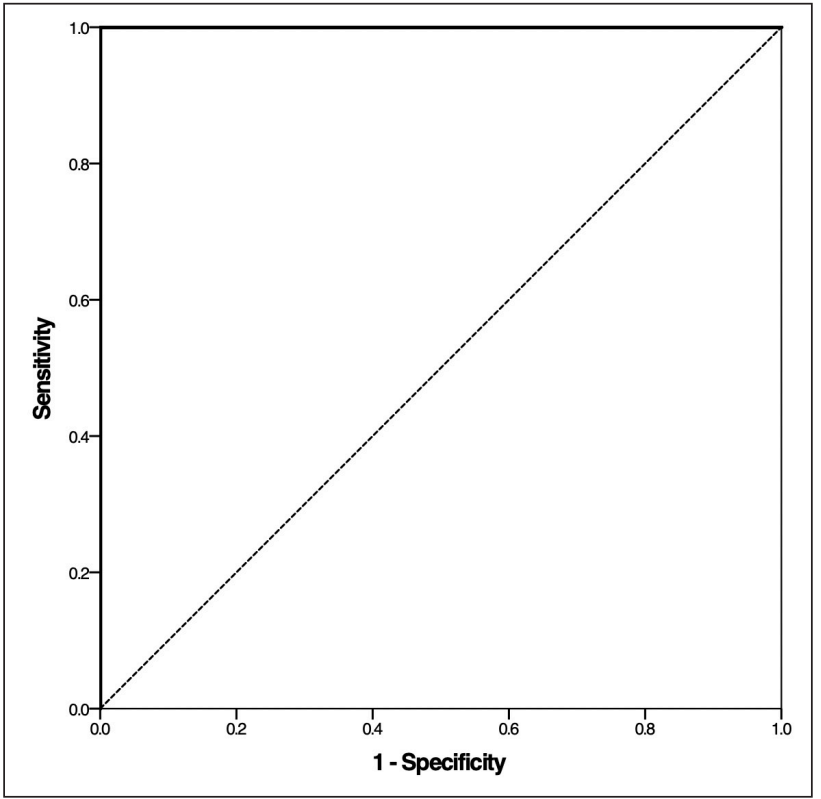

Commentary: The area under the ROC curve (1.000) signifies perfect diagnostic accuracy. A threshold score of 7 was determined for the recognition of tinnitus. The ROC curve was created by plotting $\mathrm{P}_{\mathrm{THI}}$ and $\mathrm{CT}_{\mathrm{TH}}$.

Figure 4. THI ROC curve.

COMQ-12 and DHI had excellent, NVI acceptable and THI perfect diagnostic accuracies according to $A_{\text {ROC }}(58)$. There is no similar data published for $\mathrm{DHI}, \mathrm{NVI}$ and $\mathrm{THI}$ in other languages regarding diagnostic accuracy and cut-off values by determining $A_{\text {ROC }}$ and Youden's index.

\section{CONCLUSION}

The COMQ-12, DHI, NVI and THI questionnaires were cross-culturally adapted and validated in the Slovenian language for the first time. The questionnaires can be used in diagnosis or for evaluating the treatment outcome. It is therefore an efficient and essential tool for the comprehensive management of patients with chronic otitis media, dizziness and tinnitus. They are useful for general practitioners, occupational health specialists, neurologists and otorhinolaryngologists. In the future, the COMQ-12, DHI, NVI and THI questionnaires could also assist a physician in their choice of the most appropriate treatment modality, via their implementation to disease-management guidelines. However, further research is needed to substantiate the usefulness of these questionnaires for different types of chronic otitis media, vertigo and tinnitus. The relationships between the questionnaires and other diagnostic tests should also be considered. The Slovenian COMQ-12, DHI, NVI and THI could be used in research into new treatment efficacies 
and into the impact of treatment on a patient's healthrelated quality of life. As we live in a digital era, the future lies in electronic questionnaires, which are easier to access and complete and aid the data analysis process.

\section{ACKNOWLEDGEMENTS}

John Phillips, Gary P. Jacobson, Emilia Lacroix and Craig W. Newman for permission to translate the original COMQ$12, \mathrm{DHI}, \mathrm{NVI}$ and $\mathrm{THI}$, respectively.

\section{CONFLICTS OF INTEREST}

The authors declare that no conflicts of interest exist.

\section{FUNDING}

There is no financial interest or risk.

\section{ETHICAL APPROVALS}

Received from the Republic of Slovenia National Medical Ethics Committee (Nos 0120-146/2019/5, 0120-032/2016-2 and $21 / 6 / 15$ )

\section{REFERENCES}

1. Zelko E, Švab I, Pavlič Rotar D. Quality of life and patient satisfaction with family practice care in a Roma population with chronic conditions in northeast Slovenia. Zdr Varst. 2015;54(1):18-26. doi: 10.1515/sjph2015-0003.

2. Štern B, Hojs Fabjan T, Rener-Sitar K, Zaletel-Kragelj L. Validation of the Slovenian version of Multiple Sclerosis Quality of Life (MSQOL-54) instrument. Zdr Varst. 2017;56(4):260-7. doi: 10.1515/sjph-2017-0035.

3. Grosek J, Košir JA, Novak J, Omejc M, Tomažič A, Norčič G. Validation of the Slovenian version of the Low Anterior Resection Syndrome score for rectal cancer patients after surgery. Zdr Varst. 2019;58(4):148-54. doi: 10.2478/sjph-2019-0019.

4. Urbančič J, Soklič Košak T, Jenko K, Božanić Urbančič N, Hudoklin P, Delakorda M, et al. Cross-cultural adaptation and validation of Nasal Obstruction Symptom Evaluation questionnaire in Slovenian language. Zdr Varst. 2016;56(1):18-23. doi: 10.1515/sjph-2017-0003.

5. Doruk C, Çelik M, Kara H, Polat B, Güldiken Y, Orhan KS. Turkish translation and validation of Chronic Otitis Media Questionnaire-12. Turk Arch Otorhinolaryngol. 2019;57(1):24-9. doi: 10.5152/ tao.2019.3693.

6. Nikitas C, Kikidis D, Katsinis S, Kyrodimos E, Bibas A. Translation and validation of the Dizziness Handicap Inventory in Greek language. Int J Audiol. 2017;56(12):936941. doi: 10.1080/14992027.2017.1370559.

7. Lacroix E, Deggouj N, Salvaggio S, Wiener V, Debue M, Edwards MG. The development of a new questionnaire for cognitive complaints in vertigo: the Neuropsychological Vertigo Inventory (NVI). Eur Arch Otorhinolaryngol. 2016;273(12):4241-9. doi: 10.1007/s00405-0164135-x.

8. Oron Y, Sergeeva NV, Kazlak M, Barbalat I, Spevak S, Lopatin AS, et al. A Russian adaptation of the Tinnitus Handicap Inventory. Int J Audiol. 2015;54(7):485-9. doi: 10.3109/14992027.2014.996823.
9. Hall DA, Domingo SZ, Hamdache LZ, Manchaiah V, Thammaiah S, Evans $C$, et al. A good practice guide for translating and adapting hearingrelated questionnaires for different languages and cultures. Int J Audiol. 2018;57(3):161-75. doi: 10.1080/14992027.2017.1393565.

10. Monasta L, Ronfani L, Marchetti F, Montico M, Vecchi Brumatti L, Bavcar A, et al. Burden of disease caused by otitis media: systematic review and global estimates. PLoS One. 2012;7(4):e36226. doi: 10.1371/ journal.pone.0036226.

11. Adoga A, Nimkur T, Silas O. Chronic suppurative otitis media: socioeconomic implications in a tertiary hospital in Northern Nigeria. Pan Afr Med J. 2010;4(3). doi: 10.11604/pamj.26/01/2010 .4.3.158.

12. Maile EJ, Youngs R. Quality of life measures in otitis media. J Laryngol Otol. 2013;127(5):442-7. doi: 10.1017/S0022215113000509.

13. Bakir S, Kinis V, Bez Y, Gun R, Yorgancilar E, Ozbay M, et al. Mental health and quality of life in patients with chronic otitis media. Eur Arch Otorhinolaryngol. 2013;270(2):521-6. doi: 10.1007/s00405-0122031-6.

14. Phillips JS, Haggard M, Yung M. A new health-telated quality of life measure for active chronic otitis media (COMQ-12): development and initial validation. Otol Neurotol. 2014;35(3):454-8. doi: 10.1097/ MAO.0000000000000205.

15. Bächinger D, Röösli C, Ditzen B, Huber AM. Development and validation of the Zurich chronic middle ear inventory (ZCMEI-21): an electronic questionnaire for assessing quality of life in patients with chronic otitis media. Eur Arch Otorhinolaryngol. 2016;273(10):3073-81. doi: 10.1007/s00405-016-3915-7.

16. Phillips JS, Yung MW. COMQ-12 scores in adult patients without chronic middle ear disease. Clin Otolaryngol. 2014;39(6):362-7. doi: 10.1111/ coa.12306.

17. Fonseca ACO, Ramos P, Balsalobre FA, Freitas E, Phillips JS, Yung MW, et al. Validation of a Portuguese version of the health-related quality of life measure for active chronic otitis media (COMQ-12). Braz J Otorhinolaryngol. 2018;84(6):708-12. doi: 10.1016/j.bjorl.2017.08.007.

18. Prabhu P, Chandrashekar A, Jose A, Ganeshan A, Kiruthika L. Development and administration of chronic suppurative otitis media questionnaire-12 (COMQ-12) and Chronic Otitis Media Outcome Test-15 (COMOT-15) in Kannada. Int Arch Otorhinolaryngol. 2018;22(02):10812. doi: $10.1055 / \mathrm{s}-0037-1603644$.

19. Bukurov B, Arsovic N, Grujicic SS, Haggard M, Spencer H, Marinkovic JE. Psychometric characteristics of the Chronic Otitis Media Questionnaire 12 (COMQ-12): stability of factor structure and replicability shown by the Serbian version. Health Qual Life Outcomes. 2017;15(207). doi: 10.1186/s12955-017-0782-x.

20. Oorts E, Phillips JS, Van de Heyning P, Yung M, Van Rompaey V. Dutch health-related quality of life measure for chronic otitis media. B-ENT. 2015;11(4):291-5.

21. van Dinther J, Droessaert V, Camp S, Vanspauwen R, Maryn Y, Zarowski $A$, et al. Validity and test-retest reliability of the Dutch version of the Chronic Otitis Media Questionnaire 12 (COMQ-12). J Int Adv Otol. 2015;11(3):248-52. doi: 10.5152/lao.2015.1701.

22. Bisdorff A, Bosser G, Gueguen R, Perrin P. The epidemiology of vertigo, dizziness, and unsteadiness and its links to co-morbidities. Front Neurol. 2013;4:29. doi: 10.3389/fneur.2013.00029.

23. Ciorba A, Bianchini C, Scanelli G, Pala M, Zurlo A, Aimoni C. The impact of dizziness on quality-of-life in the elderly. Eur Arch Otorhinolaryngol. 2017;274(3):1245-50. doi: 10.1007/s00405-016-4222-z.

24. Bronstein AM, Golding JF, Gresty MA, Mandalà M, Nuti D, Shetye A, et al. The social impact of dizziness in London and Siena. J Neurol. 2010;257(2):183-90. doi: 10.1007/s00415-009-5287-z.

25. Duracinsky M, Mosnier I, Bouccara D, Sterkers O, Chassany O, Working Group of the Société Française d'Oto-Rhino-Laryngologie (ORL). Literature review of questionnaires assessing vertigo and dizziness, and their impact on patients' quality of life. Value Health. 2007;10(4):273-84. doi: 10.1111/j.1524-4733.2007.00182.x.

26. Yip CW, Strupp $M$. The Dizziness Handicap Inventory does not correlate with vestibular function tests: a prospective study. J Neurol. 2018;265(5):1210-8. doi: 10.1007/s00415-018-8834-7. 
27. Jacobson GP, Newman CW. The development of the Dizziness Handicap Inventory. Arch Otolaryngol Head Neck Surg. 1990;116(4):424-7. doi: 10.1001/archotol.1990.01870040046011.

28. Jarlsäter S, Mattsson E. Test of reliability of the Dizziness Handicap Inventory and the Activities-specific Balance Confidence scale for use in Sweden. Adv Physiother. 2003;5(3):137-44. doi: $10.1080 / 14038190310004385$.

29. Chen W, Shu L, Wang Q, Pan H, Wu J, Fang J, et al. Validation of 5-item and 2-item questionnaires in Chinese version of Dizziness Handicap Inventory for screening objective benign paroxysmal positional vertigo. Neurol Sci. 2016;37(8):1241-6. doi: 10.1007/s10072-016-25732.

30. Vereeck L, Truijen S, Wuyts F, Van de Heyning PH. Test-retest reliability of the Dutch version of the Dizziness Handicap Inventory. B-ENT. 2006;2(2):75-80.

31. Karapolat H, Eyigor S, Kirazli Y, Celebisoy N, Bilgen C, Kirazli T. Reliability, validity and sensitivity to change of Turkish Dizziness Handicap Inventory (DHI) in patients with unilateral peripheral vestibular disease. J Int Adv Otol. 2009;5:237-45.

32. Colnaghi S, Rezzani C, Gnesi M, Manfrin M, Quaglieri S, Nuti D, et al. Validation of the Italian version of the Dizziness Handicap Inventory, the Situational Vertigo Questionnaire, and the Activity-specific Balance Confidence scale for peripheral and central vestibular symptoms. Front Neurol. 2017;8:528. doi: 10.3389/fneur.2017.00528.

33. Kurre A, van Gool CJAW, Bastiaenen CHG, Gloor-Juzi T, Straumann $D$, de Bruin ED. Translation, cross-cultural adaptation and reliability of the German version of the Dizziness Handicap Inventory. Otol Neurotol. 2009;30(3):359-67. doi: 10.1097/MAO.0b013e3181977e09.

34. Pérez N, Garmendia I, Martín E, García-Tapia R. Cultural adaptation of 2 questionnaires for health measurement in patients with vertigo. Acta Otorrinolaringol Esp. 2000;51(7):572-80.

35. The Neuropsychological Vertigo Inventory (NVI). Accessed September 23th, 2019 at: http://www.nvi-questionnaire.com/en/.

36. Degeest S, Corthals P, Dhooge I, Keppler H. The impact of tinnitus characteristics and associated variables on tinnitus-related handicap. J Laryngol Otol. 2016;130(1):25-31. doi: 10.1017/S0022215115002716.

37. Moring J, Bowen A, Thomas J, Bira L. The emotional and functional impact of the type of tinnitus sensation. J Clin Psychol Med Settings. 2016;23(3):310-8. doi: 10.1007/s10880-015-9444-5.

38. Bartels H, Pedersen S, Laan B van der, Staal M, Albers F, Middel B. The impact of type $D$ personality on health-related quality of life in tinnitus patients is mainly mediated by anxiety and depression. Otol Neurotol. 2010;31(1):11-8. doi: 10.1097/MAO.0b013e3181bc3dd1.

39. Hoekstra CEL, Wesdorp FM, van Zanten GA. Socio-demographic, health, and tinnitus related variables affecting tinnitus severity. Ear Hear. 2014;35(5):544-54. doi: 10.1097/AUD.0000000000000045.

40. Skarżyński PH, Rajchel JJ, Gos E, Dziendziel B, Kutyba J, Bieńkowska $\mathrm{K}$, et al. A revised grading system for the Tinnitus Handicap Inventory based on a large clinical population. Int J Audiol. 2020;59(1):61-7. doi: 10.1080/14992027.2019.1664778.

41. Ristovska L, Jachova Z, Stojcheska V. Psychoacoustic characteristics of tinnitus in relation to audiometric profile. Arch Acoust. 2019;44(3):41928. doi: 10.24425/aoa.2019.129258.

42. Newman CW, Jacobson GP, Spitzer JB. Development of the Tinnitus Handicap Inventory. Arch Otolaryngol Head Neck Surg. 1996;122(2):1438. doi: 10.1001/archotol.1996.01890140029007.

43. Bencsik B, Tamás L, Trimmel K, Stauder A. Hungarian adaptation of the Tinnitus Handicap Inventory: reliability and validity. Eur Arch Otorhinolaryngol. 2015;272(9):2243-8. doi: 10.1007/s00405-014-31388.

44. Zachariae R, Mirz F, Johansen LV, Andersen SE, Bjerring P, Pedersen CB. Reliability and validity of a Danish adaptation of the Tinnitus Handicap Inventory. Scand Audiol. 2000;29(1):37-43. doi: 10.1080/010503900424589.
45. Wrzosek M, Szymiec E, Klemens W, Kotyło P, Schlee W, Modrzyńska $M$, et al. Polish translation and validation of the Tinnitus Handicap Inventory and the Tinnitus Functional Index. Front Psychol. 2016;7:1871. doi: 10.3389/fpsyg.2016.01871.

46. Jun HJ, Yoo IW, Hwang SJ, Hwang SY. Validation of a Korean version of the tinnitus handicap questionnaire. Clin Exp Otorhinolaryngol. 2015;8(3):198-201. doi: 10.3342/ceo.2015.8.3.198.

47. Schmidt LP, Teixeira VN, Dall'Igna C, Dallagnol D, Smith MM. Brazilian Portuguese language version of the "Tinnitus Handicap Inventory": validity and reproducibility. Braz J Otorhinolaryngol. 2006;72(6):80810. doi: 10.1016/S1808-8694(15)31048-X.

48. Aksoy S, Firat Y, Alpar R. The Tinnitus Handicap Inventory: a study of validity and reliability. Int Tinnitus J. 2007;13(2):94-8.

49. Monzani D, Genovese E, Marrara A, Gherpelli C, Pingani L, Forghieri $M$, et al. Validity of the Italian adaptation of the Tinnitus Handicap Inventory; focus on quality of life and psychological distress in tinnitus-sufferers. Acta Otorhinolaryngol Ital. 2008;28(3):126-34.

50. Kam ACS, Cheung APP, Chan PYB, Leung EKS, Wong TKC, van Hasselt CA, et al. Psychometric properties of the Chinese (Cantonese) Tinnitus Handicap Inventory. Clin Otolaryngol. 2009;34(4):309-15. doi: 10.1111/j.1749-4486.2009.01946.x

51. Meng Z, Zheng Y, Liu S, Wang K, Kong X, Tao Y, et al. Reliability and validity of the Chinese (Mandarin) Tinnitus Handicap Inventory. Clin Exp Otorhinolaryngol. 2012;5(1):10-6. doi: 10.3342/ceo.2012.5.1.10.

52. Ghulyan-Bédikian V, Paolino M, Giorgetti-D’Esclercs F, Paolino F. Psychometric properties of a French adaptation of the Tinnitus Handicap Inventory. Encephale. 2010;36(5):390-6. doi: 10.1016/j. encep.2009.12.007.

53. Bolduc D, Désilets F, Tardif M, Leroux T. Validation of a French (Québec) version of the Tinnitus Handicap Inventory. Int J Audiol. 2014;53(12):903-9. doi: 10.3109/14992027.2014.935495.

54. Oron Y, Shushan S, Kreitler S, Roth Y. A Hebrew adaptation of the Tinnitus Handicap Inventory. Int J Audiol. 2011;50(6):426-30. doi: 10.3109/14992027.2011.561503

55. Ruopp MD, Perkins NJ, Whitcomb BW, Schisterman EF. Youden Index and optimal cut-point estimated from observations affected by a lower limit of detection. Biom J. 2008;50(3):419-30. doi: 10.1002/ bimj. 200710415.

56. Koo TK, Li MY. A guideline of selecting and reporting intraclass correlation coefficients for reliability research. J Chiropr Med. 2016;15(2):155-63. doi: 10.1016/j.jcm.2016.02.012.

57. Liu YF, Locklear TD, Sharon JD, Lacroix E, Nguyen SA, Rizk HG. Quantification of Cognitive Dysfunction in Dizzy Patients Using the Neuropsychological Vertigo Inventory. Otol Neurotol. 2019;40(7):e72331. doi: 10.1097/MA0.0000000000002311.

58. Mandrekar JN. Receiver operating characteristic curve in diagnostic test assessment. J Thorac Oncol. 2010;5(9):1315-6. doi: 10.1097/ JTO.0b013e3181ec173d. 